\title{
Reform and Innovation of College English Teaching under the Background of Internet+ Era
}

\author{
Hongtu Ren \\ Feixian Campus, Linyi University, China \\ 435995789@qq.com
}

Keywords: Internet+ era; College English teaching; Reform; Innovation

\begin{abstract}
At present, how to effectively integrate modern information technology with the qualified internet resources into college English teaching becomes the focus of the English teaching reform and construction of diversified classroom teaching research in colleges and universities. In recent years, the advanced teaching means with the combination of network and and classroom teaching such as MOOC, micro class, open class video and flipping classroom have achieved good results, which not only a vanguard and exemplary role for the promotion of quality of college English teaching, but also greatly promotes the innovation of teaching models, making a great contribution to the cultivation of English talents quality and practical ability.
\end{abstract}

\section{The Challenge to College English Teaching under the Background of Internet+ Era}

With the coming of internet+ era, the integration of emerging technologies and college English teaching subverted traditional English teaching concepts and models. First, college students can make use of internet learning resources anywhere and anytime in the internet+ era, this greatly enhances autonomy and selectivity of learning and it not only meet the needs of students' individualized exploration and study but also improve study interest and efficiency. However, the college students are facing a bit of challenges under this background, the social demand for talents is also on the basis of internet+ in the future. Therefore, it requires the students not only to have goog knowledge, but also to acquire the latest knowledge, especially the English knowledge by the internet+. Only in this way can they become high-quality talents. [1] Second, the internet+ brings new challenge and opportunity to the college English teaching. Spoon-feeding or knowledge-feeding teaching is a main model of English classroom teaching in the past, it's hard to guarantee the students' main body status. Therefore, this makes students feel dull, boring, lacking in interest and enthusiasm and it's difficult to achieve the expected objective of learning effect. Under the background of internet + , the rise of various interactive learning platforms and learning software not only enrich the the organization forms and methods of classroom teaching but also make teachers make good use of internet resources and modern information technology, and then make the organization of teaching content rich and effective. At last, informationized teaching environment requires the teachers to improve their concepts, professional work and skills, and thus effectively meet the requirements of teaching reform in the new period of tome. Meanwhile, MOOC, micro class, flipping classroom and other new teaching methods also require the teachers to follow the trend and keep pace with the times, especially improve the ability of making use of internet technology and integrating internet resources. The teachers should apply teaching strategy reasonably and flexibly and make English teaching become a new chapter of informationized college English classroom.

\section{The Necessity of College English Teaching Reform and Innovation under the Background of Internet+ Era}

At present, promoting all-around college English teaching reform is an inevitable trend of the era development and it is also an important guarantee of improving the quality of personnel training and meet the need of the employers. It is generally known that college English teaching reform is a system engineering and it needs to grope way constantly and achieve upgrade and perfection step 
by step. Meanwhile, internet+ provides resources and practical resources to the teaching reform and innovation and create a whole new, practical and convenient development space. Therefore, making advantage of the internet is an important way to promote college English teaching reform. It can effectively implement the achievements of reform and innovation only by linking teaching reform and network information closely. The current college English teaching in our country contains two forms, one is general English which improve the students' ability of mastering English by setting up general English course. The other is professional English, its training objective is to cultivate specialized talents that engage English-related jobs.

With the social development and the deepening of china's reform and opening up, we soberly realize the importance of talents to the national development when we focus on the economic and cultural construction. Colleges can play a big role in every aspects of the society only having cultivated the professional quality English talents., then they can contribute to the enhancement of comprehensive national strength. Therefore, it is imperative to integrate information technology and the reform and innovation of college English teaching under the background of "internet+".

\section{Present situation of college English classroom teaching}

At present, most of the college English teaching is stale and conservative. The teachers dominate the classroom teaching and take up most of the time, the main teaching form is implantation or explanation and the students have to accept passively. Meanwhile the teachers spend too much time on explanation, which is bad for effective interaction between teachers and students. The phenomenon that students can't solve the problems they encounter in the class is widely exist. As time goes by, the students will accumulate more and more problems and thus cause the mood of students study-weariness. Besides, lecture teaching model will cause the decline of students' learning enthusiasm and initiative. The teachers explain volubly in the class, but neglect the students' feelings and psychological needs. Students' interests are not roused and initiative consciousness can't be activated, therefore, the teaching effect is heavily discounted. At last, English teachers emphasis the theories on the book and grammatical knowledge too much, but despise the development of students' practical competence. This is the main factor that lead to English majors present unprofessional state.[3]

\section{Problems in the college English classroom teaching methods}

The multimedia teaching has become the dominant of the classroom. Many college English teachers simply think that network teaching is the application of multimedia, they make multimedia as the dominant of the classroom. On the one hand, they turn the original PPT into network video resources without any processing or make a little change, and then continuously play and use. Although it can relieve the tension of the class, it is harmful to the cultivation of practical English talents from the perspective of effectiveness and pertinence. On the other hand, it may make the students have an illusion that the teachers don't focus on the classroom teaching, they may feel the teachers don't respect them and then lose the interest of English learning. Furthermore, it's bad for the cultivation of practical English talents to apply too much multimedia teaching. This is also the main problem in college English class at this stage.[4]

Multimedia production pay too much attention to technology. As the colleges will carry out the teaching evaluation regularly, this can promote the English teachers' profession competence and teaching level. On the other hand, it also virtually increases the teacher' pressure and burden. College English teachers have to prepare and design multimedia teaching courseware for their demonstration class in order to obtain a good result. At the same time, English teachers continuously increase the proportion of the multimedia technology to have unique style and improve the enthusiasm of students' participation. This will lead to ignoring and deviating English teaching contents. As is well known, the purpose of teaching evaluation is to promote the teaching reform and reflect teaching innovation, however, pay too much attention to information technology will go against the original intention of teaching reform. 
Deeply influenced by the traditional teaching model. College English teaching has always been dominated by the traditional inherent model, teachers are the center of classroom teaching and students' dominant position can't be established. Therefore, the confidence and desire of the student' English learning are not strong. In addition, the single teaching model and methods make students understand difficultly. Deeply influenced by the traditional teaching ideas, it's difficult to combine this two teaching models and carry out in school. Therefore, it's not an easy thing to make college English classroom go out of the traditional model under the background of internet+ era. It not only needs teachers and students raise awareness, coordinate and continuously try and improve the integration of information technology and classroom teaching, but also needs colleges increase investment in English teaching and create a good software and hardware teaching atmosphere.

\section{Comparison and Analysis Between the Teaching Model under the Background of the Internet+ and Traditional Teaching Model}

The teaching model under the background of the internet+. Compared with the traditional teaching model, the teaching model under the background of the internet+ has irreplaceable role and advantage. First, teaching operation is more convenient and flexible and can achieve personality and autonomy of teaching demand in the form of curriculum because it is based on the internet. In addition, it increase students' learning passion and sense of participation and stimulates students ' enthusiasm. Second, it can ensure the achievement of teaching reform principles which carry forward the dominant learning position of students, effectively cultivate students' comprehensive utilization ability and enlarge student's vision. At last, it is beneficial to achieve diversified teaching methods. Through online teaching under the internet+, teachers can continuously reflect, discover and perfect themselves to find their shortage and gap, then optimize step by step by self diagnosis and practice. However, the college students' self-learning ability needs to be improved and have strong dependence on teachers' face to face guidance at the present stage. Therefore, it's difficult to ensure the students self-study by making use of internet resources in their spare time, this is the key problem that the teaching models are facing under the background of internet+.

The traditional teaching model. There is a severe challenge to the traditional teaching model under the background of internet+. Of course, the traditional teaching model also has its own characteristics and can't be negated completely. Although there is some sense of inculcation and force in the teaching process, it has a degree of supervised effect before the students don't form the habit of self-studying. With the expansion of the scale of higher education, some students who have poor foundation in English have some prejudice and depression to English learning and haven't completely formed a good learning habit. Therefor, it can improve these students' English score by applying traditional teaching model properly, at least can increase their basic ability and skills when they take exam or grading test. But the disadvantages of traditional teaching model is obvious, the students can't play their subject advantage in the class and enjoy joy during the study.

\section{The College English Teaching Reform under the Background of Internet+.}

Constructing the teaching model under the environment of internet+. The teaching model under the environment of internet+ is a process of integrating internet and classroom. It is very important to construct internet+ learning platform in this process. The teachers and students need to discuss and explore with each other to enhance the depth and breadth of teaching in class. After class, in order to make study plan and program for the students, we should encourage students to make use of the internet study platform to self-study, make them effectively absorb what they have learned and then promote sustainable development of English study.

Accumulating personalized English resource library. Under the background of internet+, the importance of English resource library is self-evident. With the development of information technology, we should try our best to make students contact with different kinds of language materials and this is crux to improve students' language input channel. Therefore, college English study can't be limited to classroom, after all classroom time is limited. Based on this, improving the 
students' consciousness and creating personalized English resource library for them is the matter that college teachers must think seriously and confront. The teachers should encourage students to persevere and form a good habit of self-studying.

The teaching model of micro class. Micro class is a new model of English online teaching under the background of internet+. It's convenient for students to study at any time by recording short and refined intellectual content and then sharing them to students. Micro class teaching requires teachers to carefully prepare and design, highlight objectivity and subjectivity and thus create a diversified teaching atmosphere.

Establishing mobile internet teaching system. College English teaching reform should also make good use of the function of full coverage of internet, and then integrate teaching management, course teaching, independent study, interactive communication and earning assessment, establish a complete mobile internet teaching system to achieve effective and ordered running of teaching management, ensure dynamic, scientific and standard management of the mobile internet teaching system and promote efficiency, extensibility and sustainability of the teaching management.

\section{The innovation of college English teaching under the background of internet+.}

With the development of society, concern at the quality of college education is growing with each passing day. This put forward new requirements for the innovation of college English teaching model. Relative to college English major, the purpose of establishing innovative teaching model is to serve for increase teaching efficiency. Therefore, the advantage of applying internet information innovation to English teaching is mainly reflected in the following aspects:

Analyzing from the learner. The college English classroom teaching in our country, the condition that followed the traditional teaching mode has not changed effectively. It's difficult to achieve effective and personalized development if students are passive in teaching and their learning initiative are very low. Therefore, under the background of internet+, the openness and diversification of knowledge can provide high-quality teaching resources for students and the communication is also timely, effective and convenient by internet teaching. In addition, the mobile interactive teaching model makes teaching activities not limited to classroom and a wider network teaching platform can provide real-time teaching contents and materials for learners.

Analyzing from the teacher. Most college English teaching are teacher-centered at present, the application of courseware is very fluent. Therefore, the construction of college English teaching innovation mechanism must take the teacher as breakthrough. The teacher is inductor of class teaching as well as the user of some new teaching models, such as micro class and MOOCs. Teaching reform can be executed deeply and effectively only by raising teachers' innovative consciousness and abilities.

Making use of shared teaching resources of open courses. Under the background of internet+, with the expanding choice space of teaching model, more high-quality resources can be shared by means of internet platform and then construct open a network teaching environment. College English class can try using mobile equipment and APP application and choose some programs which are well-organized and have practical value of English teaching, and then stimulate students' interest in learning, blending teaching into amusement and then relieve students' fear and get twice the result with half the effort.

Refining teaching content with online teaching methods. Intelligent mobile devices are popular gradually in the age of internet. Therefore, college English teaching should make use of WeChat, QQ and other new medias to carry out online centralized instructions or one-on-one tutoring. Online instruction not only has strong practicability and pertinence but also help to refine teaching content, making different problems resolved timely and then better improve students' language learning ability and efficiency.

The arrival of internet+ era brings new chance and challenge for college English teaching reform and innovation. The practice has proved that traditional teaching ideals and models have disjointed the development of the society. Therefore, it becomes an important teaching reform subject to blend information technology and English class. College English teachers should conform with the 
development of internet era and pay more attention to information reform.

\section{References}

[1] Q. Zhang and Z. Zhu: Inheritance and Innovation of the Textbook Compilation and Publication under the Background of Internet+, J. A Vast View on Publishing, (2016) No. 22, p75-77.

[2] S. Gao and Y.H. Xu: Innovative Research on the English Teaching in the Internet Age, J. Theory and Practice of Education. (2016) No. 35, p2.

[3] L. Yang: College English Teaching Reform and Innovation in the Internet Age, J. University Education Science, (2016) No. 4, p145.

[4] N. Ji and H.Y. Shao: English Teaching Reform under the Background of the Development of Network Technology.Theory and Practice of Education. (2016) No. 26, p2.

[5] Yu D, Peng L. When does Inferring Reputation Probability Countervail Temptation in Cooperative Behaviors for the Prisoners' Dilemma Game? [J]. Chaos, Solitons \& Fractals, 2015, 78: 238-244. 